\title{
Trypanocidal activity of salinomycin is due to sodium influx followed by cell swelling
}

\author{
Dietmar Steverding ${ }^{*}$ and Darren W Sexton
}

\begin{abstract}
Background: The few currently available drugs for treatment of African trypanosomiasis are outdated and show problems with toxicity and resistance. Hence, there is an urgent need for the discovery and development of new anti-trypanosomal agents.

Findings: In this study, the ionophorous antibiotic salinomycin was investigated for its trypanocidal activity in vitro using culture-adapted bloodstream forms of Trypanosoma brucei. The concentrations of salinomycin to reduce the growth rate by $50 \%$ and to kill the parasites were $0.31 \mu \mathrm{M}$ and $1 \mu \mathrm{M}$, respectively. The trypanocidal action of the ionophore was shown to be the result of an influx of $\mathrm{Na}^{+}$resulting in an increased intracellular $\mathrm{Na}^{+}$concentration followed by cell swelling. This mode of action differs from the mechanism for the anti-cancer activity of salinomycin reported to be by induction of apoptosis.
\end{abstract}

Conclusion: Here we have shown that salinomycin is an effective agent against bloodstream forms of T. brucei and might be a potential candidate for treatment of African trypanosomiasis.

Keywords: African trypanosomiasis, Trypanosoma brucei, Salinomycin, Drug screening

\section{Findings \\ Background}

African trypanosomes are the etiological agents of sleeping sickness in humans and nagana disease in cattle. The parasites are transmitted by the bite of infected tsetse flies and live and multiply in the blood and tissue fluids of their mammalian hosts. Both sleeping sickness and nagana disease occur in sub-Saharan Africa between $14^{\circ}$ North and $20^{\circ}$ South latitude, the distribution area of tsetse flies [1]. In this so-called tsetse belt, millions of people and cattle are at risk of getting infected with the parasites [2,3]. In addition, it is estimated that nagana disease costs the affected African countries over 1 billion USD per year [3]. Chemotherapy of African trypanosomiasis still relies on a few drugs developed decades ago, most of which show poor efficacy and significant toxicity, and are being increasingly subject to drug resistance [4]. Thus, new drugs are urgently needed for chemotherapy of sleeping sickness and nagana disease. One approach for the discovery of new drugs for treatment of African

\footnotetext{
* Correspondence: D.Steverding@uea.ac.uk

BioMedical Research Centre, Norwich Medical School, University of East Anglia, Norwich Research Park, Norwich NR4 7TJ, UK
}

trypanosomiasis is the screening of existing drugs for trypanocidal activities [5].

Salinomycin (Figure 1) is a carboxylic polyether antibiotic produced by a strain of Streptomyces albus [6]. It is a monovalent cation ionophore mediating the transport of $\mathrm{Na}^{+}, \mathrm{K}^{+}$and $\mathrm{Rb}^{+}$(but not of $\mathrm{Cs}^{+}, \mathrm{Mg}^{2+}, \mathrm{Ca}^{2+}$ and $\mathrm{Sr}^{2+}$ ) across organic phases [7]. The antibiotic is widely used as a food supplement to control coccidiosis in poultry $[8,9]$ and has recently received attention as a novel cancer drug candidate [10]. However, compounds displaying anti-cancer activity usually also exhibit strong trypanocidal activity [11-13]. In this study, we investigated the trypanocidal activity of salinomycin and the underlying mechanism of action of the antibiotic using bloodstream forms of Trypanosoma brucei.

\section{Methods}

The trypanocidal activity of salinomycin was determined with bloodstream forms of the T. brucei clone 427-221 [14] while the general cytotoxicity of the ionophore was evaluated with human HL-60 cells and normal PBMCs (peripheral blood mononuclear cells). Cells were seeded in 24-well plates in a final volume of $1 \mathrm{ml}$ of appropriate culture medium (trypanosomes: Baltz medium [15];

\section{C)




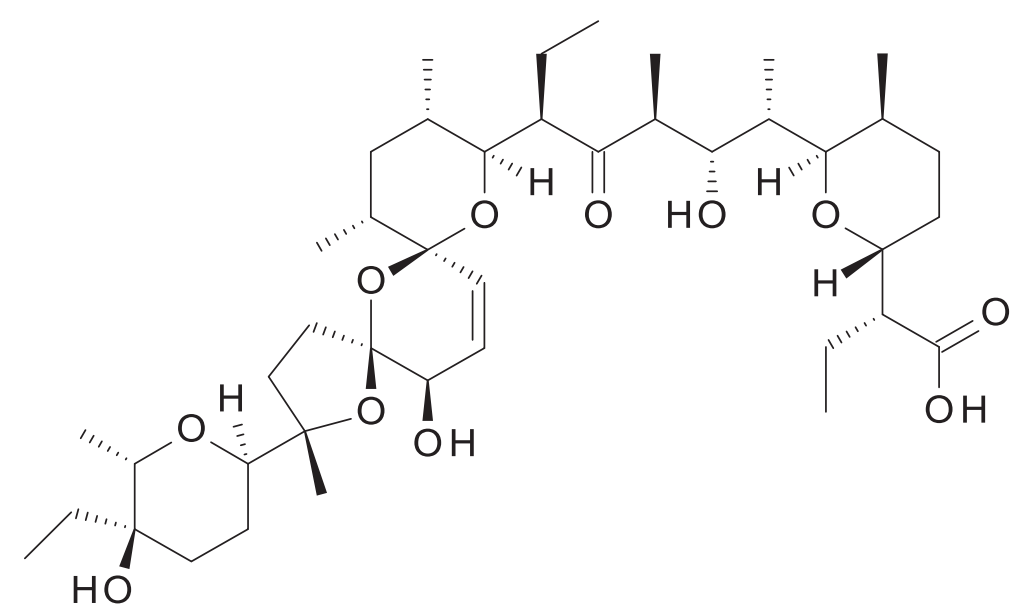

Figure 1 Structure of salinomycin.

human cells: RPMI medium [16]) supplemented with $16.7 \%(\mathrm{v} / \mathrm{v})$ heat-inactivated foetal bovine serum and containing various concentrations of salinomycin $\left(10^{-4}\right.$ to $10^{-9} \mathrm{M}$ ) and $1 \%$ DMSO. Wells containing medium and $1 \%$ DMSO served as controls. The initial cell densities were $1 \times 10^{4} / \mathrm{ml}$ for trypanosomes, $1 \times 10^{5} / \mathrm{ml}$ for HL-60 cells and $5 \times 10^{5} / \mathrm{ml}$ for PBMCs. After $24 \mathrm{~h}$ incubation, $100 \mu \mathrm{l}$ of a $0.44 \mathrm{mM}$ resazurin solution prepared in PBS was added and the cells were incubated for a further $48 \mathrm{~h}$. Thereafter, the plates were read on a microplate reader using a test wavelength of $570 \mathrm{~nm}$ and a reference wavelength of $630 \mathrm{~nm}$. The $50 \%$ growth inhibition $\left(\mathrm{GI}_{50}\right)$ value (trypanosomes and HL-60 cells) and the 50\% effective concentration $\left(\mathrm{EC}_{50}\right)$ value (PBMCs), i.e., the concentration of salinomycin necessary to reduce the growth rate of cells by $50 \%$ or to cause an effect in $50 \%$ of cells compared to the control, were determined from mean values using the 4-parameter logistic model [17]. The following formula for the 4-parameter logistic model was used: $Y=$ $\left\{[a-d] /\left[1+(X / c)^{b}\right]\right\}+d$, where $Y$ is the response, $X$ is the concentration, $a$ is the lower asymptote (lower plateau), $d$ is the upper asymptote (upper plateau), $b$ is the slope factor (Hill factor) and $c$ is the $\mathrm{GI}_{50} / \mathrm{EC}_{50}$ value. The minimum inhibitory concentration (MIC) value, i.e. the concentration of salinomycin at which all cells were killed, was determined microscopically by inspecting each well thoroughly for the presence of any motile trypanosomes or unlysed HL-60s or PBMCs.

Changes in cell volume were measured using a previously described light scattering method [18]. Bloodstream forms of $T$. brucei were seeded at a density of $5 \times 10^{7}$ cells $/ \mathrm{ml}$ in 96-well plates in a final volume of $200 \mu \mathrm{l}$ culture medium containing $100 \mu \mathrm{M}$ salinomycin and $0.5 \%$ DMSO (test) or $0.5 \%$ DMSO alone (control). Absorbance of the cultures was measured at $490 \mathrm{~nm}$ every $15 \mathrm{~min}$. A decrease in absorbance corresponded to an increase in cell volume.
Cell morphology changes were examined by light microscopy. Briefly, bloodstream forms of T. brucei were treated at a density of $5 \times 10^{7}$ cells $/ \mathrm{ml}$ with $100 \mu \mathrm{M}$ salinomycin and $0.5 \%$ DMSO (test) or $0.5 \%$ DMSO alone (control). After $1 \mathrm{~h}$ incubation, cells were fixed with $2 \%$ formaldehyde $/ 0.05 \%$ glutaraldehyde in PBS, spread onto slides and air dried. The smears were stained with May-Grünwald staining solution and then imaged with a Zeiss Axioplan 2 fluorescence microscope using a Plan-Apochromat $100 \times / 1.4$ oil objective.

The intracellular level of $\mathrm{Na}^{+}$was monitored with Sodium Green ${ }^{\text {Ta }}$ tetraacetate, a cell-permeant indicator for the fluorometric determination of $\mathrm{Na}^{+}$concentration. The probe can freely diffuse across cell membranes and is intracellularly converted into the $\mathrm{Na}^{+}$-responsive acidic form by esterases. Trypanosomes were incubated at a density of $5 \times 10^{7}$ cells $/ \mathrm{ml}$ with $100 \mu \mathrm{M}$ salinomycin and $0.5 \%$ DMSO (test) or $0.5 \%$ DMSO alone (control) in the presence of $4 \mu \mathrm{M}$ Sodium Green ${ }^{\mathrm{Tm}}$ tetraacetate for $1 \mathrm{~h}$. After washing twice with culture medium, cells were then immediately analysed by flow cytometry using a BD Accuri C6 flow cytometer. The excitation wavelength was $488 \mathrm{~nm}$ and the filter set was $530 / 30 \mathrm{~nm}$. Gates were set to exclude cell fragments and debris from the analysis, and 50,000 gated cells were analysed.

\section{Results and discussion}

Salinomycin showed a dose-dependent effect on the growth of $T$. brucei bloodstream forms with a $\mathrm{GI}_{50}$ value of $0.17 \mu \mathrm{M}$ and a MIC value of $1 \mu \mathrm{M}$ (Figure 2). The ionophore displayed similar cytotoxic activity against leukaemic HL-60 cells with a $\mathrm{GI}_{50}$ value of $0.29 \mu \mathrm{M}$ and a MIC value of $1 \mu \mathrm{M}$ (Figure 2). Similar antiproliferative activity has been recently reported for various other cancer cells including human promyelocytic leukaemia cells $\left(\mathrm{IC}_{50}=0.44 \mu \mathrm{M}[19]\right)$, human colon adenocarcinoma 


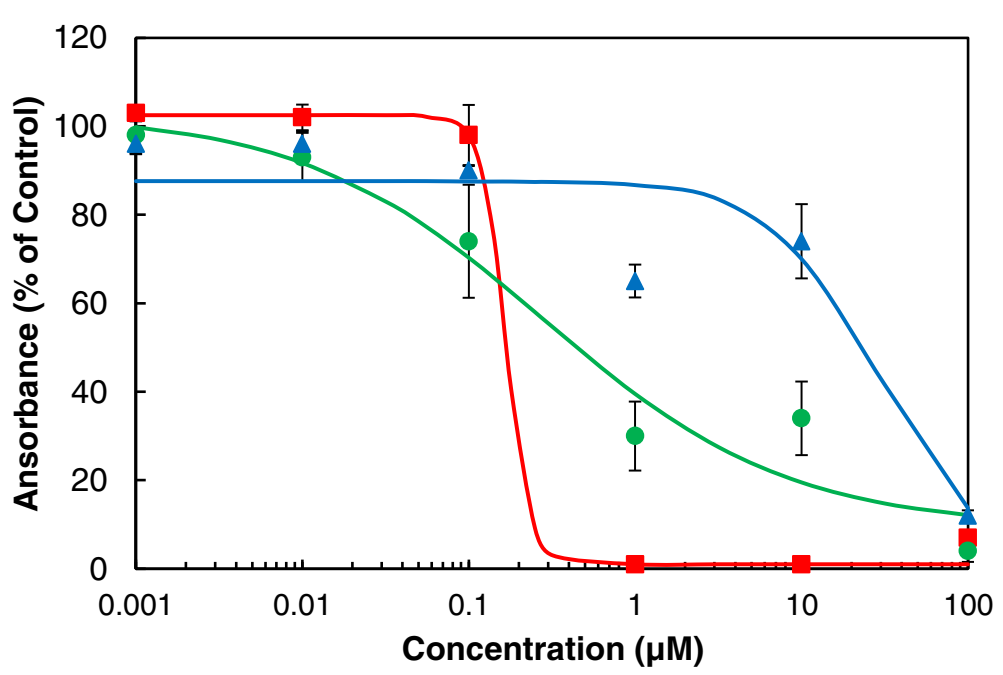

Figure 2 Trypanocidal and cytotoxic effects of salinomycin. Bloodstream forms of T. brucei (red squares), HL-60 cells (green circles) and PBMCs (blue triangles) were incubated with varying concentrations of salinomycin. After $72 \mathrm{~h}$ of culture, cell viability and proliferation were determined with the colorimetric dye resazurin. Mean values \pm SD of three (PBMCs) or four (T. brucei and HL-60) experiments are shown. Dose-response curves were calculated from mean values using the 4-parameter logistic model.

cells $\left(\mathrm{IC}_{50}=1.11 \mu \mathrm{M}[19]\right)$ and $\mathrm{VCaP}$ prostate carcinoma cells $\left(\mathrm{EC}_{50}=0.38 \mu \mathrm{M}[20]\right)$. In contrast to the effect on cancer cells, it was reported that salinomycin is $10-100$ times less cytotoxic against non-malignant cells $[19,20]$. In fact, salinomycin exhibited only low cytotoxicity against normal PBMCs with an $\mathrm{EC}_{50}$ value of $29.9 \mu \mathrm{M}$ and a MIC value of $100 \mu \mathrm{M}$ (Figure 2). This latter finding indicates that the ratio for cytotoxic/trypanocidal activity (selectivity index) for salinomycin is in a moderate range.

One obvious mechanism of action of salinomycin would be its effect as an ionophore on the depolarisation of membrane potentials. By using the fluorescent probe 3,3'-dihexyloxycarbocyanine, however, it was found that salinomycin did not affect the membrane potential of bloodstream forms of T. brucei (data not shown). This observation is in agreement with previous findings that valinomycin also did not influence the membrane potential of trypanosomes, although the parasites are extremely sensitive to this ionophore [21].

Another possible mechanism of action of salinomycin could be that the ionophore increases the intracellular cation level followed by a quick entry of water which would lead to cell swelling and damage of intracellular structures. Changes in cell volume can be monitored spectrophotometrically by following the absorbance of the cell suspension at $490 \mathrm{~nm}$. Incubation of bloodstream forms of $T$. brucei with $100 \mu \mathrm{M}$ salinomycin resulted in a decrease of absorbance over time while the absorbance of control cultures did not change (Figure 3). It should be noted that a much higher concentration of salinomycin was needed (100 $\mu \mathrm{M}$ compared to $1 \mu \mathrm{M}$ necessary to kill all cells in the growth inhibition assay shown in Figure 2) in order to observe a measurable effect on the swelling of trypanosomes in a short period of time. This is because that at high cell density, which is required for the recording of changes in cell volume, bloodstream forms of $T$. brucei do not survive for a very long time in culture. The decrease in absorbance corresponded to cell swelling as judged from visual observation by light microscopy. Parasites treated for $1 \mathrm{~h}$ with $100 \mu \mathrm{M}$ salinomycin lost the normal elongated shape of trypanosomes and appeared as rounded up cells (Figure 4). The only monovalent cations

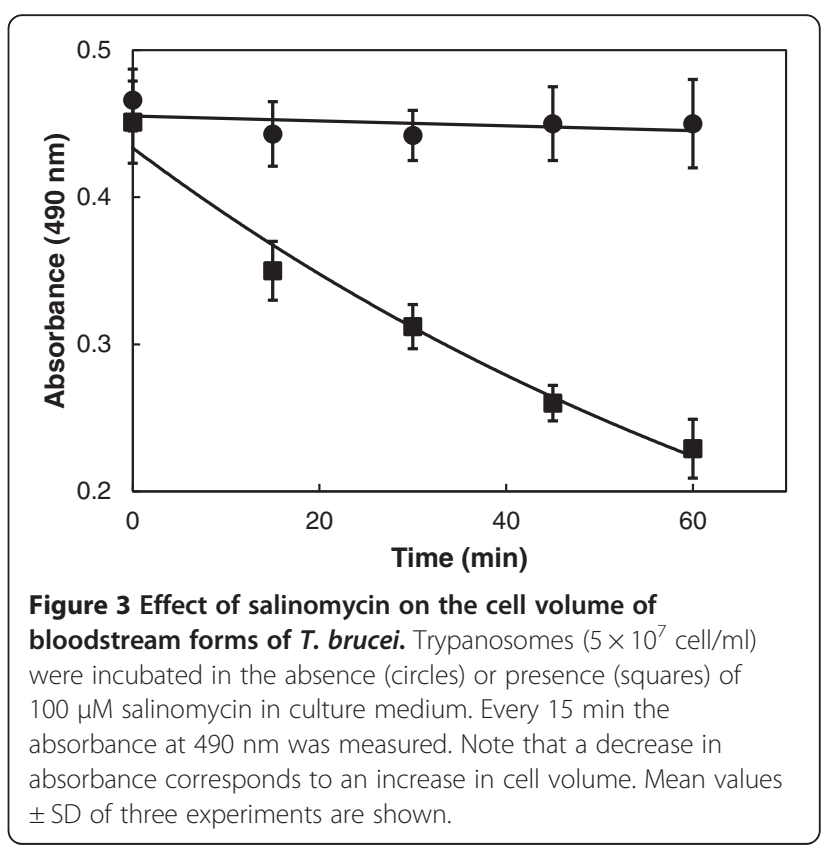


present within bloodstream forms of $T$. brucei and in the culture medium are $\mathrm{Na}^{+}$and $\mathrm{K}^{+}$. Thus, only these may be involved in the cell swelling observed in the presence of salinomycin. As bloodstream forms of T. brucei are low$\mathrm{Na}^{+}$and high- $\mathrm{K}^{+}$cells [22], only a salinomycin-mediated transport of $\mathrm{Na}^{+}$from the exterior to the interior could explain the observed cell swelling. To prove that the cause of the swelling was indeed due to an increased intracellular $\mathrm{Na}^{+}$level, the concentration of $\mathrm{Na}^{+}$was determined with the fluorescent probe Sodium Green $^{\mathrm{Tm}}$ tetraacetate. Subsequent flow cytometry revealed that trypanosomes treated with $100 \mu \mathrm{M}$ salinomycin for $1 \mathrm{~h}$ had a much higher fluorescence signal than control cells (Figure 5). The median fluorescence intensity signal for salinomycintreated parasites was $2223 \pm 164(\mathrm{n}=3)$ and for control parasites it was $1050 \pm 345(\mathrm{n}=3)$. This result indicates that upon incubation with salinomycin, the intracellular $\mathrm{Na}^{+}$concentration was raised more than twofold in the trypanosomes from $13.7 \mathrm{mM}$ [22] to about $30 \mathrm{mM}$. This increase in $\mathrm{Na}^{+}$concentration is enough to explain the swelling of trypanosomes by entry of water. For instance, subjection of bloodstream forms of T. brucei to a reduction in osmolarity from 300 to 150 mOsm (which in turn can be regarded as a twofold increase in the intracellular concentration of solute particles) results in a dramatic initial swelling of the cells [23].

\section{Conclusion}

This study has demonstrated that the ionophore salinomycin displays trypanocidal activity by a mechanism involving increased $\mathrm{Na}^{+}$influx followed by subsequent cell swelling which is probably due to the uptake of water. This mechanism is different from the mode of action reported for the anti-cancer activity of salinomycin. Recent research has shown that salinomycin induces apoptosis in cancer cells by different mechanisms, which include increasing the intracellular levels of reactive oxygen species (ROS) [24] and inhibiting the Wnt signalling pathway [25]. However, we did not find any evidence that

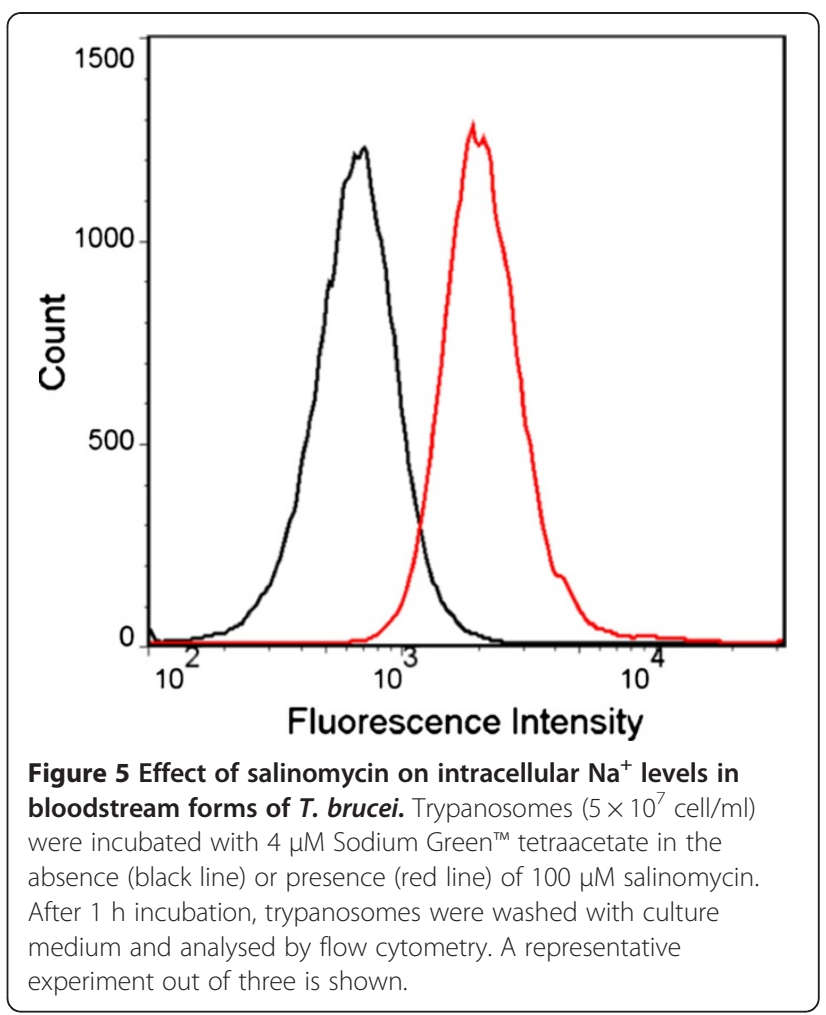

the trypanocidal activity of salinomycin is associated with the induction of apoptosis in bloodstream forms of $T$. brucei (data not shown).

Importantly, salinomycin can be administered orally whereas most of the current drugs used for treatment of African trypanosomiasis have to be given parenterally. Before developing salinomycin into an anti-trypanosomal agent, animal experiments are needed to establish the in vivo trypanocidal activity of the ionophore. However, a selectivity index of 10-100 may be inadequate for proceeding with animal studies as it is recommended that such animal experiments should only be pursued if the selectivity index is greater than 100 [26]. Despite this, salinomycin may serve as a lead for the development of

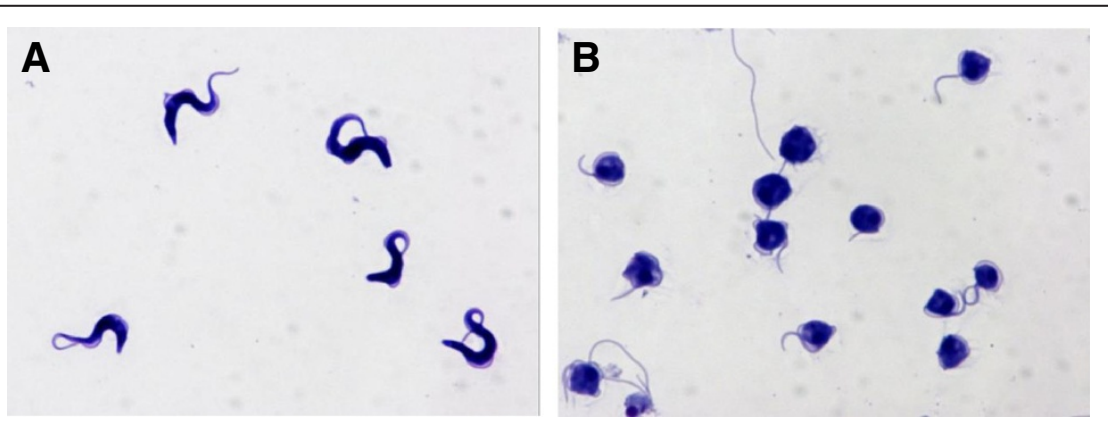

Figure 4 Effect of salinomycin on the morphology of bloodstream forms of $\boldsymbol{T}$. brucei. Trypanosomes $\left(5 \times 10^{7}\right.$ cell/ml) were incubated in the absence (A) or presence (B) of $100 \mu \mathrm{M}$ salinomycin for $1 \mathrm{~h}$. Formaldehyde/glutaraldehyde-fixed cells were spread onto slides, air dried and stained with May-Grünwald staining solution. A representative experiment out of three is shown. 
derivatives with improved trypanocidal activities. In addition, the ionophore could be used in combination with current anti-trypanosomal drugs. In recent years, such a drug combination regime (eflornithine/nifurtimox) has been successfully introduced for the treatment of human African sleeping sickness [27].

\section{Competing interests}

The authors have no competing interests.

\section{Authors' contribution}

DS designed the experiments. DS and DWS performed the experiments. DS drafted the manuscript. DWS edited the manuscript. Both authors read and approved the final manuscript.

\section{Acknowledgements}

We thank Dr Andrew Goldson for his help in preparing the graphs of the flow cytometry analysis.

Received: 8 January 2013 Accepted: 18 March 2013

Published: 21 March 2013

\section{References}

1. Molyneux DH, Pentreath V, Doua F: African trypanosomiasis in man. In Manson's Tropical Diseases. 20th edition. Edited by Cook GC. London: W.B. Saunders; 1996:1171-1196.

2. World Health Organization: Trypanosomiasis, human African (sleeping sickness). World Health Org Fact Sheet 2012, 259. http://www.who.int/ mediacentre/factsheets/fs259/en/.

3. Kristjanson PM, Swallow BM, Rowlands GJ, Kruska RL, de Leeuw PN: Measuring the costs of African animal trypanosomiasis, the potential benefits of control and returns to research. Agr Sys 1999, 59:79-98.

4. Delespaux V, de Koning HP: Drugs and drug resistance in African trypanosomiasis. Drug Resist Updat 2007, 10:30-50.

5. Caffrey $C R$, Steverding D: Recent initiatives and strategies to developing new drugs for tropical parasitic diseases. Expert Opin Drug Discov 2008, 3:173-186.

6. Miyazaki Y, Shibuya M, Sugawara H, Kawaguchi O, Hirose C, Nagatsu J, Esumi S: Salinomycin, a new polyether antibiotic. J Antibiot (Tokyo) 1974, 27:814-821.

7. Mitani M, Yamanishi T, Miyazaki Y: Salinomycin: a new monovalent cation ionophore. Biochem Biophys Res Commun 1975, 66:1231-1236.

8. Chapman HD: Use of anticoccidial drugs in broiler chickens in the USA: analysis for the years 1995 to 1999. Poult Sci 2001, 80:572-580.

9. Chapman HD, Johnson ZB: Use of antibiotics and roxarsone in broiler chickens in the USA: analysis for the years 1995 to 2000. Poult Sci 2002, 81:356-364.

10. Huczynski A: Salinomycin: a new cancer drug candidate. Chem Biol Drug Des 2012, 79:235-238.

11. Deterding A, Dungey FA, Thompson KA, Steverding D: Anti-trypanosomal activities of DNA topoisomerase inhibitors. Acta Trop 2005, 93:311-316.

12. Steverding $D$, Wang $X$ : Trypanocidal activity of the proteasome inhibitor and anti-cancer drug Bortezomib. Parasit Vectors 2009, 2:29.

13. Steverding D, Wang X, Potts BC, Palladino MA: Trypanocidal activity of B-lactone-y-lactam proteasome inhibitors. Planta Med 2012, 78:131-134.

14. Hirumi H, Hirumi K, Doyle JJ, Cross GAM: In vitro cloning of animal-infective bloodstream forms of Trypanosoma brucei. Parasitology 1980, 80:371-382.

15. Baltz T, Baltz D, Giroud C, Crockett J: Cultivation in a semi-defined medium of animal infective forms of Trypanosoma brucei, T. equiperdum, T. evansi, T. rhodesiense and T. gambiense. EMBO J 1985, 4:1273-1277.

16. Moore GE, Gerner RE, Franklin HA: Culture of normal human leukocytes. J Am Med Assoc 1967, 199:519-524.

17. Finney DJ: Statistical method in biological assay. 3rd edition. London: Charles Griffin \& Co: 1978

18. Park JH, Schofield PJ, Edwards MR: Giardia intestinalis: volume recovery in response to cell swelling. Exp Parasitol 1997, 86:19-28.

19. Huczyński A, Janczak J, Antoszczak M, Wietrzyk J, Maj E, Brzezinski B: Antiproliferative activity of salinomycin and its derivatives. Bioorg Med Chem Lett 2012, 22:7146-7150.
20. Ketola K, Hilvo M, Hyötyläinen T, Vuoristo A, Ruskeepää AL, Orešič M, Kallioniemi O, Iljin K: Salinomycin inhibits prostate cancer growth and migration via induction of oxidative stress. Br J Can 2012, 106:99-106.

21. Mosimann M, Goshima S, Wenzler T, Lüscher A, Uozumi N, Mäser P: A Trk/ HKT-type $\mathrm{K}^{+}$transporter from Trypanosoma brucei. Eukaryot Cell 2010, 9:539-546.

22. Nolan DP, Voorheis HP: Factors that determine the plasma-membrane potential in bloodstream forms of Trypanosoma brucei. Eur J Biochem 2000, 267:4615-4623.

23. Bassarak B, Uzcátegui NL, Schönfeld C, Duszenko M: Functional characterization of three aquaglyceroporins from Trypanosoma brucei in osmoregulation and glycerol transport. Cell Physiol Biochem 2011, 27:411-420.

24. Kim KY, Yu SN, Lee SY, Chun SS, Choi YL, Park YM, Song CS, Chatterjee B, Ahn SC: Salinomycin-induced apoptosis of human prostate cancer cells due to accumulated reactive oxygen species and mitochondrial membrane depolarization. Biochem Biophys Res Commun 2011, 413:80-86.

25. Lu D, Choi MY, Yu J, Castro JE, Kipps TJ, Carson DA: Salinomycin inhibits Wnt signaling and selectively induces apoptosis in chronic lymphocytic leukemia cells. Proc Natl Acad Sci USA 2011, 108:13253-13257.

26. Nwaka S, Hudson A: Innovative lead discovery strategies for tropical diseases. Nat Rev Drug Discov 2006, 5:941-955.

27. Simarro PP, Franco J, Diarra A, Postigo JA, Jannin J: Update on field use of the available drugs for the chemotherapy of human African trypanosomiasis. Parasitology 2012, 139:842-846.

doi:10.1186/1756-3305-6-78

Cite this article as: Steverding and Sexton: Trypanocidal activity of salinomycin is due to sodium influx followed by cell swelling. Parasites \& Vectors 2013 6:78.

\section{Submit your next manuscript to BioMed Central and take full advantage of:}

- Convenient online submission

- Thorough peer review

- No space constraints or color figure charges

- Immediate publication on acceptance

- Inclusion in PubMed, CAS, Scopus and Google Scholar

- Research which is freely available for redistribution 